\title{
aniki
}

Revista Portuguesa da Imagem em Movimento

Portuguese Journal of the Moving Image

\section{Atores em Kiarostami Do mundo iraniano para o palco italiano}

\author{
Alexandre Wahrhaftig ${ }^{1}$
}

\section{Corpos no mundo}

A questão de colocar um corpo em cena para interpretar um personagem não é nada simples para Abbas Kiarostami. A questão do "ser outro" atravessa toda sua obra e faz de cada cena e de cada corpo um território de jogo entre o ser imaginário e o ser real que o interpreta, entre o personagem e o ator. O fato de Kiarostami constantemente trabalhar com atores não profissionais faz com que a questão do "ser outro" esteja sempre, de alguma forma, presente, mas é em Close-up (Close-up - namay-e nazdik, 1990) e em Através das oliveiras (Zir-e derakhtan-e zeytun, 1994) que ela atinge pontos de radicalização, tornando-se uma questão incontornável para se pensar tais filmes (e, em perspectiva, joga luz sobre outros filmes). Close-up é uma reconstrução de uma história que já traz em si o tema do "ser outro": Sabzian é um homem condenado por se passar pelo cineasta Makhmalbaf, enganando uma família burguesa de Teerã. No filme, a história é reencenada pelas próprias pessoas que a viveram e, assim, Sabzian novamente volta a atuar, dessa vez interpretando a si mesmo enquanto interpreta outro. Essa estrutura em abismo é reencontrada, de maneira distinta, em Através das oliveiras: Hossein interpreta a si mesmo enquanto trabalha como ator não profissional para um diretor que se vê constantemente às voltas com as dificuldades de fazer de Hossein um "outro" para o filme dentro do filme.

Dada tal trajetória, como podemos compreender, então, os novos contornos que a questão do "ser outro" adquire em Cópia fiel (Copie conforme, 2010)? A tematização da questão está, certamente, presente na narrativa. Feito na Toscana, na Itália, o filme acompanha o dia de passeio de Elle, uma francesa que possui uma loja de antiguidades em Arezzo, com James Miller, um escritor inglês que está ali para o lançamento de seu livro acerca do valor da cópia das obras de arte. Os dois desconhecidos, em uma espécie de flerte romântico, vão, aos poucos, transformando-se em marido e mulher casados há quinze anos, mas que se mantêm, estranhamente, desconhecidos sob determinados prismas. Ultrapassando uma constatação de ambiguidade, a trama constrói um grande paradoxo que envolve a afirmação simultânea das múltiplas identidades desses corpos: ser e não ser, ao mesmo tempo, esposa e marido.

\footnotetext{
${ }^{1}$ Escola de Comunicações e Artes/Universidade de São Paulo, CEP 05508-020 São Paulo, SP, Brasil.
} 
Para além do escopo narrativo - paradoxal e nada simples -, uma questão fundamental vem à tona de maneira mais incisiva ao nos depararmos com esse filme: por que tais corpos? Por que elencar uma atriz francesa de fama internacional (Juliette Binoche) e um cantor de ópera inglês (William Shimell) para os papeis principais? Por que colocá-los lado a lado? Há alguma dinâmica de tensão entre ator e personagem aqui? O que mais salta aos olhos no elenco de Cópia fiel é o fato de estarmos diante de profissionais - ainda que nem todos de cinema. E isso se torna um problema de análise, na medida em que, se considerarmos a obra de Kiarostami, notamos que o ator profissional lhe é uma figura, se não ausente, pelo menos bastante rara (quase a ser evitada).

Logo, em vez da pergunta que se costumou fazer a seu cinema durante décadas e que atravessou diversas entrevistas feitas com o diretor - "por que elencar atores não profissionais?" - devemos colocar outra: "por que elencar profissionais?”. Quando vemos um filme narrativo, raramente nos perguntamos por que o diretor preferiu profissionais ao invés de buscar pessoas do cotidiano. O problema foi naturalizado, mas não quer dizer que não esteja lá. No caso de Kiarostami, dada sua trajetória, é impossível passarmos "naturalmente" pelo fato de que Cópia fiel seja um filme feito por atores profissionais (sejam eles de cinema ou de ópera). Antes, porém, de investigarmos as escolhas de Cópia fiel, é prudente esboçarmos uma espécie de síntese do que constitui o trabalho de Kiarostami com os atores não profissionais em sua filmografia, ainda que esta não seja unívoca quanto a tal questão.

As justificativas que Kiarostami traz em diversos depoimentos para o seu trabalho com atores não profissionais são pautadas por um forte compromisso com o realismo ${ }^{2}$. Lembrando-se de filmes a que assistira na juventude, o diretor ressalta como no cinema italiano (particularmente no neorrealista) lhe impressionara o fato de que os personagens eram semelhantes às pessoas que o cercavam, sua família e amigos (Ishaghpour; Kiarostami 2004, 197). Isso certamente diz respeito às representações das histórias de tais personagens (imbricadas no cotidiano), mas também remete à fisionomia, aos rostos e gestos dos não profissionais (em contraposição às estrelas).

No primeiro curta de Kiarostami, O pão e o beco (Nan va kuche, 1970), o compromisso com o realismo atravessou suas preocupações com decupagem, mise en scène e, logicamente, incidiu sobre o elenco. Assertivo em sua decisão por usar atores não profissionais, o diretor afirma com humor: "fiz meu primeiro filme com um menino de 8 anos,

\footnotetext{
${ }^{2} \mathrm{O}$ realismo com o qual Kiarostami se compromete possui traços em comum com o ideário baziniano de uma estética ambígua e transparente, mergulhada no tempo e na profundidade do mundo, mas não se basta nessa definição e pode, muitas vezes, contradizer tal modelo. O grau de reflexividade dos filmes, de metalinguagem e de ruptura com o universo ficcional, somado a um olhar mais baziniano poroso às ambiguidades do real, faz do realismo de Kiarostami algo bastante singular, sempre tensionado, mas jamais abandonado.
} 
um homem de 80 anos e um cão vira-lata, todos não profissionais"3. Essa primeira experiência inaugurou uma forma de trabalho com atores que se desenvolveu e se desdobrou em muitas de suas filmagens posteriores. Trata-se de uma forma que privilegia poucas rupturas entre o tempo da cena e o tempo da filmagem (daí a preferência pelos planos-sequência), uma forma que justamente elabora uma temporalidade distante das exigências de causalidade mais esquemática, com um olhar atento às modulações cotidianas $\mathrm{e}$ aos deslocamentos dos corpos pelos espaços reais das locações.

O trabalho com não profissionais possui, portanto, duas faces: o método e o resultado; o processo e o filme projetado; o ator e o personagem. Certamente implicados um no outro, muitas vezes misturados perversamente, essas faces não são sempre indistinguíveis. No âmbito do resultado, diríamos que Kiarostami visa o realismo. O realismo de Kiarostami circunscreve a criação de um mundo (ficcional) muito próximo ao cotidiano, em um tom menor, sem grandes heróis, sem grandiloquência espetacular. Depoimentos do diretor a respeito da forma de decupagem e de mise en scène caminham nessa direção, evitando exageros de movimento de câmera e de cortes na montagem (Ishaghpour; Kiarostami 2004, 203).

A ideia de trazer rostos desconhecidos para a tela funciona também nessa chave. Ao trazer um ator não profissional e, portanto, não familiar ao público dos cinemas, cria-se um universo no qual a identidade do personagem adere com força ao corpo do ator. O espectador não possui uma imagem prévia daquele corpo e, portanto, não o associa a outros personagens. Mais do que isso, também não o associa à ideia de fabricação de ilusão, de ficção. ${ }^{4} \mathrm{O}$ aspecto documental do cinema de Kiarostami, que provém muitas vezes da integração na narrativa de elementos pouco "dramáticos" (não integrados numa ordem de causa e efeito evidente) e de uma forma que preza pela continuidade espaço-temporal, certamente se beneficia da presença de atores não profissionais em cena. A aderência do personagem ao corpo pode ser tamanha que chega a gerar nos espectadores a dúvida quanto ao caráter fictício das imagens e sons dos filmes (o que, evidentemente, não ocorre em Cópia fiel).

Kiarostami insiste em buscar atores cuja aderência ao personagem seja quase total: "Eu nunca mudei a idade de um ator com maquiagem ou com algum outro artifício, e tampouco mascarei sua personalidade pedindo-o para interpretar outro papel que não o seu próprio. Quando um personagem deve ser iletrado, eu contrato um

\footnotetext{
3 Comentários do diretor extraídos da parte 7 do filme Dez sobre 10 (Ten on 10, 2001). Tradução nossa a partir da versão em inglês do filme.

${ }^{4}$ Ao comentar as diferenças entre documentário e ficção, Jean-Luc Godard conta uma anedota simbólica que, apesar de extremamente simples, guarda alguma graça para pensarmos tais suposições de ficção. Ele diz que, quando vemos num filme uma mulher andando de costas na rua, estamos diante de um documentário. Mas se essa mulher vira seu rosto e revela-se como sendo Kim Novak, o filme vira uma ficção (Godard 1989, 117).
} 
intérprete iletrado" (Ciment; Goudet 1995, 16). ${ }^{5}$ Tal depoimento, mesmo se exagerado, é revelador de um desejo de não falsear os atores. Tudo pode ser inventado no filme (cenários, roteiro etc.), mas os atores devem levar a verdade de si para os personagens que interpretam.

Se enxergamos verdade na atuação desses corpos em seu cinema, isso não se deve simplesmente ao fato de tais corpos interpretarem a si mesmos e pertencerem à realidade social e cultural que o filme representa. Há uma especificidade de atuação, de como esse corpo se coloca em cena, que exerce um forte efeito de realismo. Não podemos falar em um único "método Kiarostami" para trabalho com atores, mas observamos certas recorrências de processo ao longo de sua trajetória, que são representativas de um determinado posicionamento ético e estético da relação que seu cinema estabelece entre realidade e ficção, entre ator e personagem. Um dos elementos de tal método consiste em criar uma atmosfera na qual os atores não estejam com o roteiro decorado na ponta da língua. Mais do que isso, trata-se de criar um ambiente no qual as reações dos atores ao que acontece em cena sejam, efetivamente, reações espontâneas, não planejadas nem estudadas racionalmente. Os exemplos de tal processo são inúmeros.

Dez (Ten, 2002) é um caso paradigmático, pois nesse filme os atores encontram-se sempre dentro de um carro sem a presença da equipe técnica: duas câmeras digitais presas ao painel do veículo registravam as interações entre a motorista e os seus sucessivos passageiros. O roteiro de Dez, feito de sugestões e indicações, possibilitou aos atores participarem ativamente na criação das cenas, ainda mais estando "sozinhos" entre si. Além disso, o método de Kiarostami consistiu em certos procedimentos capazes de propiciar o surgimento do espontâneo, conforme ele mesmo explica:

procuro sempre acidentes de percurso e imprevistos nas filmagens. Dessa forma, trabalho com cada ator em separado. Nenhum conhece as falas de seu interlocutor. As respostas têm de ser surpreendentes o suficiente para dar a eles a possibilidade de encontrar um segundo estímulo para responder assim que passe o efeito surpresa. Nunca há ensaio coletivo. Tudo deve ser novo. (Ishaghpour; Kiarostami 2004, 262).

Dez é um filme cujo processo se confunde com o próprio resultado. Ele nos mergulha em uma situação que, embora não saibamos exatamente como foi feita, revela muito de seu processo pela sua forma final. Mas se pensarmos nos atores, contudo, isso não se aplica totalmente: não é possível afirmarmos quanto do filme é planejado e quanto não é. É inegável que existe algo de espontâneo acontecendo diante de nossos olhos, mas o objetivo não é nos mostrar a realidade, mas uma "verdade" como se fosse real. Todavia, a realidade do ator está intimamente ligada à impressão de realidade do filme.

5 Todas as citações das entrevistas de Kiarostami a Ciment e Goudet são de nossa tradução, a partir do original em francês. 
Kiarostami nos dá mais pormenores sobre o método ao falar da primeira cena do filme, na qual a motorista está levando o filho para a natação e este fica profundamente irritado com o fato de estarem fazendo um caminho diferente pelas ruas da cidade:

A primeira sequência entre a mãe o filho devia imperativamente ser filmada no trajeto que liga a casa deles à piscina. Caso contrário, o filho se recusaria a acreditar. Assim que mudávamos o caminho, o filho dizia: "A gente não vai à piscina, então?" A realidade e a ficção devem se aproximar o máximo possível para que a ação se torne suficientemente crível para os atores. (Ciment; Goudet 2002, 19; grifo nosso).

É importante notarmos que, segundo Kiarostami, a aproximação do real e da ficção tem como objetivo tornar a ação crível para os atores. Assim, o objetivo não é que nós, espectadores, tenhamos acesso à realidade propriamente dita, mas que os atores, ao construírem o mundo ficcional, o construam realmente, por motivações reais (e não apenas como se fosse real). O filme se constitui, portanto, como um documento de gestos efetivamente reais a serviço de um projeto ficcional.

O termo ficção, porém, carregado de uma ideia de narrativa, parece despropositado quando tratamos de um filme-dispositivo como Dez. De toda forma, encontraremos métodos muito semelhantes de trabalho em diferentes obras de Kiarostami. Em Gosto de cereja (Tam'e-ghilas, 1997), por exemplo, há também a vontade de minimizar a presença da equipe técnica ao redor dos atores, principalmente nas cenas filmadas no interior do carro, que são muitas. Elas geralmente consistem em diálogos, filmados em campo e contracampo, do motorista com um passageiro. Apesar da semelhança com Dez, aqui não há uma forma "automática" de captação. A câmera ora está no banco do passageiro, ora no banco do motorista. É surpreendente, além do mais, que os atores não tenham se encontrado no set de filmagem, pois cada um contracenava apenas com o diretor atrás da câmera. Isso parece nos distanciar da espontaneidade latente de Dez. Todavia, a ideia de filmar no carro implicava na necessidade desejada de uma equipe reduzida e o método de Kiarostami neste caso, ao contracenar com os atores, consistia em esforços para fazer com que eles se esquecessem que estavam sendo filmados e, logo, agissem de maneira real:

Eu prefiro que ela (a câmera) seja sempre discreta. Nos planos no carro, eu ficava sentado, com a câmera logo atrás de mim. Eu falo com o ator não do filme, mas da vida cotidiana. E quando sinto-o à vontade, quando sinto que ele esqueceu da câmera, eu lhe coloco a questão principal e aperto o botão para rodar. Eu suprimo, portanto, o cerimonial do "Silêncio, Rodando, Corta, Claquete", que traumatiza o ator (Ciment; Goudet 1997, 85).

Essa estratégia de tranquilizar o ator não profissional para que ele entregue ao filme gestos e palavras com motivações reais caminha 
no mesmo sentido que as intenções do diretor em não revelar o roteiro completo para seus atores. É uma forma de fazer do set um ambiente propício, não para que o ensaio se confirme - já que Kiarostami nem é adepto de ensaios -, mas para o surgimento do novo, de algo real. Os procedimentos para chegar a isso, contudo, podem ser muitas vezes invasivos, eticamente problemáticos, agressivos. Consciente disso, Kiarostami conta que, ao convidar Homayoun Ershadi, arquiteto até então desconhecido do público de cinema, para o papel principal de Gosto de cereja, alertou-o de que lhe "faria mal" e lhe "faltaria com o respeito" (Ciment; Goudet 1997, 89).

Para exemplificar essa postura, há uma história curiosa envolvendo o protagonista de Através das oliveiras. Como esboçado no início, o filme conta a história de Hossein, um rapaz iletrado a atuar nas filmagens de um outro filme - o filme dentro do filme representa, na realidade, o filme anterior de Kiarostami, $E$ a vida continua ( $\mathrm{Va}$ zendegi edame darad, 1992). Hossein, em determinado momento do filme, conversando com Keshavarz (seu diretor em cena), mostra-se indignado que ricos se casem com ricos, pois de nada serve ter duas casas, afinal "não se pode colocar a cabeça em uma e os pés em outra", segundo ele. A preparação de tal diálogo exigiu que Kiarostami convencesse Hossein de que este já lhe havia dito isso, quando se conheceram nas filmagens de $E$ a vida continua, na qual ele trabalhara de ator e assistente. Durante uma semana, nas filmagens de Através das oliveiras, Kiarostami pedia para Hossein contar a outros membros da equipe aquilo que o assistente havia lhe contado anos antes a respeito de ricos casarem-se com ricos. Com o tempo, aquela ideia foi incorporada por Hossein como sendo de fato sua (pelo menos segundo Kiarostami). Na filmagem da cena com Keshavarz, portanto, Kiarostami fez com que Hossein novamente falasse aquele texto, ao que em seguida retrucou, do fora de campo: "mas eles [o casal rico] podem habitar uma casa e alugar a outra." Frente a tal resposta, que no filme vem da boca de Keshavarz, Hossein mostra-se extremamente triste, abatido, surpreso, precisamente o que Kiarostami desejava captar (Ciment; Goudet 1995, 16).

Enfim, há um duplo movimento que atravessa os corpos de atores não profissionais em cena no cinema de Kiarostami. Por um lado, o cinema documenta a realidade desses corpos, revela-nos seus detalhes, suas formas de agir, seus sentimentos reais no dia da filmagem; por outro, o cinema captura essa realidade e a transfere para sua ficção, construindo-a com forte realismo. Não devemos, contudo, ver nesses dois polos uma oposição ou uma hierarquia. A singularidade, no caso de Kiarostami, está no cruzamento. Segundo o próprio diretor: "Tento fazer filmes que sejam ao mesmo tempo a representação de uma coisa e um acontecimento. As duas coisas ao mesmo tempo, sem ser nem uma nem outra" (Araújo apud Bernardet 2004, 151). Assim, além de visar realismo, Kiarostami visa realidade.

Segundo Jean-Claude Bernardet, apoiando-se na preparação do ator Hossein em Através das oliveiras, essa fusão de acontecimento e representação ocorre quando se fundem ator e personagem. Mesmo que se possa encarar a preparação de Hossein apenas como um 
método não ortodoxo de treinar o ator, para Kiarostami o ator só conseguiu incorporar as falas ao poder assimilá-las à sua vida. Nesse sentido, o que vemos diante da câmera é o ator e o personagem fundidos em uma mesma figura que pronuncia aquele diálogo (Bernardet 2004, 155-156).

Esse talvez seja o ponto mais singular da presença dos não atores no cinema de Kiarostami. Eles servem como um vetor para que o cinema não apenas seja representação, mas se faça como acontecimento, o que decorre da fusão ator-personagem. Essa fusão está problematizada em Através das oliveiras quando o ator Hossein, enquanto está sendo dirigido por Keshavarz, mostra dificuldade para falar, seguindo o roteiro, que morreram 65 pessoas de sua família no terremoto que assolou a região, quando na verdade morreram 25 . Ele não consegue "mentir" tão facilmente em cena, ainda que toda a construção do filme orbite segundo a lógica da "mentira", ou seja, a lógica da ficção, do falseamento, da construção.

De forma semelhante, em $E$ a vida continua, o personagem-ator Ruhi parece deixar escapar (seria ensaiado?) que a casa onde estão não é a casa dele, mas uma casa utilizada apenas para a filmagem. Desorientado nesse ambiente, ele não consegue encontrar sequer uma tigela de água para oferecer a seu visitante. A tigela acaba por lhe ser entregue por uma assistente de Kiarostami, a qual entra em quadro com o objeto de cena e logo sai. Nesse caso, o ator e o personagem entram em um conflito que é documentado pela própria câmera. Ainda que não possamos afirmar com toda a certeza se tal cena foi "planejada" ou simplesmente "aconteceu", ela é a materialização de uma fricção entre a representação que a filmagem constrói e o acontecimento que a filmagem é.

Se quisermos trazer um pouco do vocabulário que o filme Cópia fiel nos fornece para a discussão, diríamos que há um "original” em cena: o ator não profissional. Há acontecimentos originais em suas ações, verdadeiros e reais. Todavia, tais acontecimentos são fisgados pela ficção. O personagem em cena não é um original, mas uma cópia, ou seja, ele representa algo que não é; representa uma vida que não é a sua. Em alguns dos filmes que aqui citamos trata-se de um esforço por tentar fazer coincidirem cópia e original, ator e personagem. $\mathrm{Na}$ evidência de sua não-reconciliação, trata-se de expor a violência do processo: o ator que não consegue dizer o número falso de mortos no terremoto, o ator que revela não conhecer a casa em que mora no filme.

O ápice desse processo está em Close-up, filme no qual um falsário real, Sabzian, é o protagonista. Kiarostami filma o julgamento de Sabzian e, quando ele é solto, reencena a história do "crime", escalando no elenco o próprio Sabzian e os membros da família que ele enganara. O filme torna-se o encontro real, por via da ficção, dos corpos envolvidos na história. Documenta-se esse encontro, justamente a partir de sua fabricação ficcional. E a própria realidade da história é uma realidade de falsificação, de fingimento, de ficção: Sabzian é preso por "atuar", mas é também convocado, pelo filme, 
para "atuar", sendo agora ele mesmo. O filme não apenas representa uma realidade, mas engendra uma nova realidade. Não há como separar os atores de seus personagens, as atuações das realidades.

Os atores não profissionais no cinema de Kiarostami estão envolvidos, portanto, em uma complexa rede de articulações. Eles são veículo de realismo, são aproximação com a realidade, são potencialmente o acontecimento em si mesmo. Tudo isso atravessa a filmografia de Kiarostami. Assim, é com grande choque que nos deparamos, após décadas de trabalho com atores não profissionais no Irã, com um filme rodado com elenco profissional na Europa. ${ }^{6}$

\section{Corpos no palco italiano}

Cópia fiel escala Juliette Binoche no papel da protagonista feminina, o que traz de imediato consequências para o filme que extrapolam o âmbito da construção da personagem pela atriz. Em um sentido intertextual, escalar Binoche significa escalar uma grande atriz do cinema europeu, famosa internacionalmente tanto por seu trabalho em produções mais comerciais quanto por sua parceria com grandes autores do cinema mundial. Isso faz com que, de saída, Cópia fiel estabeleça um ponto de contato com um certo panteão de autores das últimas décadas, ao mesmo tempo em que marca uma distância em relação ao trabalho de Kiarostami no Irã.

A presença de Binoche configura uma pressuposição de ficção narrativa para o filme, pelo seu histórico de trabalho no cinema, que já distancia o filme dos experimentos mais radicais do diretor nos anos 2000. E Cópia fiel não desmente essa suposição: é um filme narrativo que segue um roteiro e cujos personagens são interpretados por atores profissionais. A princípio, antes mesmo de vermos o filme, uma vez que sabemos que Binoche está no elenco, já adentramos seu território esperando algum tipo de ficção narrativa ${ }^{7}$. E essa dimensão se desdobra na nossa certeza de estarmos diante de uma atriz que interpreta uma personagem, ou seja, na certeza de estarmos diante de uma construção ficcional, marcada por uma clara separação ator/personagem. Tal separação é evidente em uma primeira constatação de simplicidade ingênua: sabemos que Juliette Binoche não é uma lojista na Toscana. Sua fama, para além de sua profissão, faz dessa separação ator/personagem quase um dado.

\footnotetext{
6 Antes de Cópia fiel, Kiarostami fez no Irã dois filmes com elenco de atrizes profissionais: Shirin (2008) e Where is my Romeo? (2008) - ambos montados a partir do mesmo material bruto. Nesses, contudo, a relação das atrizes não é exatamente a de encarnarem personagens, já que todas aparecem como espectadoras de cinema; trata-se de uma aposta mais conceitual do que dramática.

7 Lembremo-nos novamente de Kim Novak (conforme nota acima). E lembremonos também de Shirin, de cujo elenco Binoche fez parte. Para um espectador pouco familiarizado com as atrizes do cinema iraniano (que vemos ao longo de Shirin sentadas em uma sala de cinema assistindo a um outro filme), a aparição de Binoche no meio do filme indica mais explicitamente a "trapaça" ficcional que o filme constrói: estariam essas mulheres assistindo mesmo a um filme no cinema? O que uma atriz francesa está fazendo entre elas, vestida de hijab?
} 
Se antes, no cinema de Kiarostami, no âmbito dos atores, estávamos imersos na dúvida de um estranho realismo (seriam essas pessoas realmente essas pessoas? isso foi ensaiado ou realmente aconteceu?), em Cópia fiel passamos para o clássico sistema de "suspensão da descrença", em que sabemos não poder acreditar no que vemos, e ainda assim adentramos o universo ficcional como se fosse real. O "palco", a separação entre vida e obra, torna-se aí evidente: faz-se palco italiano. Mas o fato de Kiarostami "adotar" tal sistema e tal profissionalismo de Binoche não é fortuito e deve ser visto com muita cautela.

O paradoxo do ator é esse: ser o que não é. O cinema de Kiarostami no Irã virou do avesso esse paradoxo, buscando as confluências entre ator e personagem, ao mesmo tempo em que expunha a tensão desse jogo. Em Cópia fiel, trata-se de abraçar tal paradoxo, o que muito condiz com o contexto (Kiarostami encontrase distante de sua realidade iraniana) e o texto da obra (um casal cujas identidades não são fixas).

O paradoxo fundante do ofício do ator, sobre o qual a filosofia muitas vezes se debruçou (tendo em Platão um grande inimigo), é defendido por Diderot, no século XVIII, como condição para o "bom" drama burguês. Segundo ele, o comediante ${ }^{8}$ deve ter a arte de tudo imitar e nenhuma sensibilidade: "se ele é ele quando representa, como deixará de ser ele?" (Diderot 1985, 162-163). Diderot qualifica o trabalho do ator por uma necessária frieza em contraposição aos acalorados homens sensíveis. Estes servem de modelo ao gênio frio do ator que, a partir deles, constrói suas cópias (Diderot 1985, 164).

Mas o que serve de modelo a Juliette Binoche para que ela possa viver essa mulher sem identidade fixa, que vive sucessivas transformações? Logicamente, incontáveis imagens de mulheres e de ideias sobre o feminino em algum ponto podem ter inspirado Binoche em seu trabalho. Entretanto, não podemos deixar de notar que há uma evidente semelhança entre as sucessivas mudanças de identidade de sua personagem (desconhecida de James, esposa de James) e o ofício do ator no cinema, como se o modelo principal da atriz fosse o seu próprio labor.

Estamos, contudo, longe de uma representação direta do ofício do ator. Não se trata de personagens que são atores diegéticos, mas de personagens que são outros sem consciência de o serem. O ofício do ator está internalizado na própria constituição desses personagens. Binoche em nenhum momento se mostra como uma pessoa que joga conscientemente entre diferentes identidades, por mais que seja tal jogo que se desenrole diante de nossos olhos. Ela está sempre imersa na verdade da personagem (ou das personagens) que vive (cf. Ishaghpour 2010, 34). Mais do que um ator incorporando personagens, parece que estamos vendo personagens atravessando o corpo de um ator. Personagens-atores e não um personagem cuja profissão consiste em atuar. Mais do que tematizar a atuação como

\footnotetext{
${ }^{8}$ Entenda-se, por comediante, ator.
} 
criação de cópias (o que aparece em Através das oliveiras), o filme vive esse processo. É como se Kiarostami não tivesse deixado de seguir sua prerrogativa de buscar uma coincidência entre ator e personagem, porém em um outro nível, incorporando na equação o profissionalismo de seu elenco.

Segundo Paulo Emílio Salles Gomes, comparando cinema com teatro, o ator do segundo se caracterizaria pela capacidade de poder criar os mais diferentes personagens, enquanto o ator do primeiro, quando já conhecido pelo público, encarna personagens iguais a si mesmo. Não no sentido em que os personagens representariam a identidade pessoal do ator, mas num sentido "mitológico": os atores conhecidos do grande público, as estrelas, acabam por se tornar personagens de ficção para a imaginação coletiva. Sua presença na tela reflete quase que inevitavelmente sua persona, sua figura mítica que foi construída em torno de si (Candido et. al. 2014, 114).

Assim, Binoche, além de profissional, é uma estrela, que não pode simplesmente se despir da persona pela qual é conhecida no mundo todo. Há uma figura mítica colada a si que não se esvai facilmente. Ao contrário, ela é quase fortalecida a cada filme que faz, ganhando mais profundidade ou reafirmando certos caracteres. Cópia fiel aproveita-se de sua posição de estrela, incorporando sua mitologia, sua persona, na construção dessa personagem fragmentada. Essa incorporação, porém, não é sem conflito. Há um deslocamento aqui que deve ser levado em conta e que nos lembra fortemente a parceria do diretor Roberto Rossellini com a atriz Ingrid Bergman, principalmente em seu filme Viagem à Itália (1954) - filme saudado como referência-matriz para Cópia fiel, com suas deambulações de um casal em crise na Itália em meio a obras de arte.

Ingrid Bergman, que já era uma estrela de fama internacional em Hollywood antes de migrar para o cinema neorrealista com Rossellini, interpreta em Viagem à Itália Katherine Joyce, mulher que está na Itália com seu marido Alex (George Sanders) para vender uma propriedade. Lá, em meio a passeios turísticos e uma conturbada convivência com o marido, Katherine se vê às voltas com lembranças de um amante já falecido. Ao final do filme, a personagem briga com Alex, sai de seu carro e, desnorteada, perde-se em meio a uma multidão em procissão. Confusa, arrastada pela massa, ela grita em desespero. Ao analisar essa sequência, Alain Bergala defende que o diretor extirpa a atriz de sua proteção (tanto da simbólica proteção de Hollywood, quanto, no filme, da proteção literal de seu carro) para lhe dar "um banho de multidão, de povo, de italianismo" (Bergala $2005,12) .{ }^{9}$ Algo de similar notamos, por exemplo, na cena da pescaria em Stromboli (1950) - primeiro filme da parceria diretor-atriz -, na qual a personagem de Bergman, uma mulher exilada em uma ilha vulcânica italiana, está sentada em um pequeno barco, observando perplexa a violência com que os peixes são fisgados e mortos, enquanto a água do mar espirra em seu rosto.

\footnotetext{
${ }^{9}$ Agradecemos a Pedro Guimarães pela referência ao texto e por sua tradução.
} 
Podemos dizer que Rossellini fez desses filmes documentários sobre a feitura dos próprios filmes (cf. Bergala 1988, 26). É um encontro real entre uma estrela hollywoodiana e a realidade italiana (a procissão, a pescaria) que está documentada nessas ficções. Para Laura Mulvey, a presença das estrelas em Viagem à Itália confirma a intenção do diretor de produzir realidade, e não realismo. Tratava-se de realmente colocar em choque tais atores com o mundo ao redor deles, com a paisagem, a geografia, o povo italiano, e não apenas criar uma ficção, mas documentar uma realidade (Mulvey 2006, 113).

$\mathrm{O}$ que em Viagem à Itália significava um diretor em casa com uma atriz estrangeira, em Cópia fiel se inverte. Agora temos um diretor estrangeiro, filmando com uma atriz que, apesar de não ser italiana, está em casa: na Europa, no "cinema de autor" (em suas proteções). Juliette Binoche rebate de maneira assertiva, em entrevista, a sugestão de que talvez Kiarostami quisesse outra coisa dela, levá-la para longe dos papeis que havia feito antes: "Acho que não, acho que ele queria ser levado para longe, e é por isso que se arriscou a fazer um filme comigo[,] [...] para quebrar sua própria imagem" (Dupont 2011, 40). ${ }^{10}$

A hipótese da atriz é contundente e coincide indiretamente com a hipótese de Youssef Ishaghpour, para quem a força de Cópia fiel está no fato de Kiarostami não ter tentado realizar um "filme de Kiarostami” fora do Irã. Segundo o crítico, o real cuja revelação vislumbramos na obra de Kiarostami é fruto de uma relação osmótica do diretor com seu país (Ishaghpour 2010, 30). Logo, filmar no Ocidente, na Itália, não pode ser equivalente a filmar no Irã. No âmbito do elenco, isso se reflete intensamente na escolha de Binoche por, primeiramente, ser uma atriz profissional e, segundo, ser uma vedete internacional em seu duplo habitat natural (a Europa e o cinema de autor). Ou seja, primeiramente, pela afirmação de um certo distanciamento entre a realidade do ator e a representação de sua personagem, como já vimos antes; segundo, pelo jogo, extra-diegético, com a mitologia da estrela.

Em oposição a Rossellini, não se trata mais de desconstruir a mitologia da estrela, dando-lhe um "banho de povo", mas de "manchar" a própria imagem de autor iraniano de Kiarostami com a marca do universo do estrelato ocidental. É uma estratégia radical e consciente de autoexílio: distante do Irã e próximo não apenas da Europa, mas do cinema de autor europeu.

Tal procedimento não é feito sem certos ruídos específicos que competem para "manchar" também a imagem da estrela protagonista. Esse é o argumento de Stéphane Delorme, para quem Kiarostami não trata sua estrela como uma estrela (Delorme 2010, 10). O crítico também aproximará o gesto de Kiarostami em relação a Binoche ao de Rossellini em relação a Bergman em Viagem à Itália, mas, enquanto a atriz sueca mantinha uma elegância fria, "a personagem de Cópia fiel possui o andar pesado, e assim que ela se detém para soltar seu sutiã

${ }^{10}$ Tradução nossa, a partir do original em inglês. 
ou massagear seus pés, isso é tudo menos erótico; sentimos a fadiga, o calor, o esforço" (Delorme 2010, 11). O autor se refere a uma cena, no final do filme, na qual Elle tira seu sutiã bege da bolsa e mostra-o para James, como prova de que entrara em uma Igreja não para rezar e sim para soltar o sutiã que estava usando. Nessa mesma cena, Elle tira o salto alto e massageia os pés.

Antes disso, a personagem já fora construída, desde o início do filme, sem qualquer glamour ou aura estelar. Ao encontrar James em sua loja, ela coça o nariz mais de uma vez, incomodada com os pelos de seu gato. Depois, quando ele se mostra ansioso por sair de sua loja, Binoche fica um tanto desconfortável, sem saber o que fazer: a postura de seu corpo curvada e abatida é "tudo menos erótica". E ao final do filme, quando ela de fato deita-se na cama do hotel, em uma tentativa de seduzir James, parece que, mais do que a sedução, o que se nota é a tentativa frustrada de uma sedução, não sem um incômodo desajuste de sua imagem.

Entretanto, com Cópia fiel, Binoche ganhou o prêmio de melhor atriz no festival de Cannes. Em outros palavras, o filme continua a elevá-la como estrela internacional. Por mais que haja ruídos, tendemos a concordar mais com Binoche do que com Delorme: o filme parece funcionar muito mais como um deslocamento para Kiarostami do que para a atriz. E, nesse ponto, os paralelos com Rossellini-Bergman devem ser feitos atentando para a inversão de sentido entre os dois trabalhos ao carregar para dentro dos filmes um universo extra-diegético. O par Rossellini-Bergman o faz no sentido de desmitificar a estrela, jogá-la no mundo real da Itália; o par Kiarostami-Binoche, no sentido de afirmar o exílio do diretor. Exílio do mundo para o palco, e para a separação que este representa.

O palco de Cópia fiel onde jogam os atores não é um palco homogêneo. Os atores não jogam todos da mesma forma, ainda que o façam no mesmo palco. Há um desequilíbrio. Enquanto a personagem feminina é interpretada por uma atriz veterana, o protagonista masculino é interpretado pelo cantor lírico Wiliam Shimell. Da diferença de registro entre os dois surgem novos elementos que corroboram para que enxerguemos a ligação e a fricção que existe entre um ator e seu personagem. Colocar uma atriz com bastante experiência ao lado de um cantor em sua primeira aparição no cinema não deve ser visto como casual.

É engraçado que Kiarostami afirme, em entrevista, ter escolhido Shimell por ele não ser ator e, portanto, para poder justamente contrapor a atuação de Binoche à de um não profissional, buscando deslocar o que seria talvez um lugar de maior conforto para a interpretação da atriz (Adams 2011). Kiarostami, porém, é surpreendido pelo que considera uma atuação "profissional" de Schimell, surpresa pouco surpreendente se considerarmos que ele escalou alguém do âmbito da mais intensa teatralidade: a ópera. Se o conflito em cena entre o profissionalismo de uma e o nãoprofissionalismo do outro em certa medida fracassou, outro conflito 
emergiu, um "conflito de jogo" 11 entre dois registros de atuação que, em mais de uma ocasião, explicitam sua desarmonia em cena. Ao invés de sermos levados à valoração opinativa típica de textos apressados de imprensa ("tal ator está mal", "tal atriz está bem"), devemos buscar uma ponderação crítica: quais as consequências dessa diferença de registros de interpretação para o discurso da obra?

Uma primeira hipótese nasce da própria abordagem aos gêneros masculino-feminino dentro do filme. A ideia de colocar uma gigante do cinema mundial ao lado de um desconhecido do mundo da ópera, que possui uma certa dureza na atuação, funciona de forma a fortalecer a personagem feminina em comparação à masculina. É difícil falar em um protagonismo único no filme, já que quase sempre os dois atores estão em cena, mas certamente há uma força, uma graça e uma complexidade na personagem feminina que são negadas ao personagem masculino. O filme segue, inegavelmente, a trilha de mergulho no universo feminino, empreendida por Kiarostami em Dez e Shirin.

Outra hipótese se abre ao pensarmos o "conflito de jogo" como um ruído na mimese ficcional. É uma forma pela qual o filme coloca em questão a "encarnação", o "ser outro", o processo pelo qual um personagem ganha corpo. Não há uma homogeneidade nesse processo, própria à ficção mimética, que estruturaria as diferentes interpretações: o jogo é multifacetado e, portanto, aponta sutilmente para si próprio. Isso fica patente quando o casal, na segunda metade do filme, senta-se em um restaurante e começa a discutir. James está de mau humor e atua de maneira exagerada: fala alto, é irônico, gesticula muito com os braços. Enquanto isso, Elle o observa triste, contida. Tudo isso é filmado em campo e contracampo com olhares frontais para a câmera (como em uma cena anterior, quando vão a um café). A atitude de James não apenas destoa muito de tudo que o seu personagem havia nos mostrado até então, como marca uma clara oposição em relação à interpretação de Binoche.

Ele, nesse momento, e pela primeira vez, mostra-se pateticamente emotivo, apresentando uma face de sua persona que até então não havíamos visto. E quando o faz, parece que é outra pessoa, totalmente diferente daquela que acompanhávamos até ali. Binoche, por outro lado, mantém um registro de interpretação constante e que não deixa de carregar estranheza para essa cena por conta de seu desequilíbrio, dada a falta de unidade entre as diferentes atuações. Se voltarmos ao texto de Diderot sobre o paradoxo do comediante, encontraremos a ideia, talvez já banalizada, de que quando um ator "ruim" contracena com um ator "bom", devem ser feitos sacrifícios pela unidade da obra (Diderot 1985, 168). Tal argumento não pode ser transplantado para uma análise de Cópia fiel, pois o filme tensiona o tempo todo a própria ideia de unidade. Afinal,

11 Expressão tomada de empréstimo da tese de doutorado de Pedro Maciel Guimarães (Criar junto: o papel dos colaboradores de criação na obra de Manoel de Oliveira, 2009, inédita) não sem alguma liberdade para transportá-la, de Manoel de Oliveira, ao universo de Cópia fiel. 
o que seria essa unidade de que Diderot fala, senão a criação de um mundo autônomo que mascare o fato de que ele é uma invenção? A partir do ponto em que os atores atuam de forma discrepante entre si, o jogo se faz visível, mesmo se nos mantivermos na ilusão da ficção. É por isso que, para Diderot, convém mais o sacrifício de um ator "bom" se "rebaixar" para se equiparar a um ator "ruim", do que correr o risco de representar uma cena sem unidade.

O conflito de jogo, ao apontar para o "fora" da ficção sugere, indiretamente, que as emoções não estão surgindo nos corpos de modo natural, mas que estão, ao contrário, sendo colocadas sobre eles. Isso corrobora a ideia de que, mais do que atores encarnando personagens, vemos os atores sendo atravessados pelos personagens. Isso é gritante na cena do restaurante quando, de uma hora para outra, James se transforma em um rabugento marido que cava no passado as falhas de sua suposta esposa Elle, ao lembrar-lhe de quando ela dormiu no volante com o filho no banco de trás. Aponta-se para o "fora" da ficção, mas sem jamais apontar para o "atrás da câmera”. Não há o não ator ao lado do ator: a realidade do ator é justamente a de ser um ator. Tudo é ficção.

O trabalho dos atores em Cópia fiel, enfim, possui uma relação ambivalente com o trabalho de Kiarostami no Irã. Por um lado, tudo se inverte: saímos do mundo e mergulhamos no palco da ficção; dos não profissionais passamos para uma vedete e um cantor de ópera; do acontecimento, para a representação com sua separação evidente ator/personagem. Por outro lado, trata-se de seguir estranhando o processo de encarnação, mas dessa vez sem se afastar da ficção em direção a um suposto real, mas mergulhado no jogo ficcional. Do interior da separação do palco, através das marcas mitológicas de Binoche e do conflito de jogo de sua interação com Shimell, Kiarostami segue se debruçando sobre o ofício do ator e sobre seu paradoxal "ser outro", questão que assombra seu cinema pelo menos desde Close-up.

\section{BIBLIOGRAFIA}

Adams, Sam. 2011. “Abbas Kiarostami”. A.V. Club, Chicago, (27 de março). Disponível em: <http://www.avclub.com/article/abbas-kiarostami-53269>. Acesso em 09/12/2013.

Bergala, Alain. 1988. "Roberto Rossellini et l'invention du cinéma moderne”. In Le cinéma révélé, de Roberto Rossellini, 9-29. Paris: Flammarion.

-——. 2005. Monika de Ingmar Bergman. Paris: Yellow Now.

Bernardet, Jean-Claude. 2004. Caminhos de Kiarostami. São Paulo: Companhia das Letras. 
Cândido, Antonio; Gomes, Paulo Emílio Salles; Prado, Décio de Almeida; Rosenfeld, Anatol. 2014. A personagem de ficção. São Paulo: Perspectiva.

Ciment, Michel; Goudet, Stéphane. 1995. "Entretien avec Abbas Kiarostami: les six faces du cube". Positif 408 (fevereiro): 1419.

-_- 1997. "Entretien avec Abbas Kiarostami: une aproche existentialiste de la vie". Positif 442 (dezembro): 83-89.

___. 2002. "Abbas Kiarostami: des femmes réelles et non de cinéma”. Positif 499 (setembro):17-21.

Delorme, Stéphane. 2010. "Imitation de la vie". Cahiers du Cinéma 656 (maio): 10-11.

Diderot, Denis. 1985. "Paradoxo sobre o comediante". In Textos escolhidos (Os Pensadores), 159-192. São Paulo: Abril Cultural.

Dupont, Joan. 2011. "My life to live: in the moment with Juliette Binoche”. Film Comment (março-abril): 38-43.

Godard, Jean-Luc. 1989. Introdução a uma verdadeira história do cinema. São Paulo: Martins Fontes.

Guimarães, Pedro. 2012. Criar junto: o papel dos colaboradores de criação na obra de Manoel de Oliveira, tese de Doutorado em Estudos Cinematograficos e Audiovisuais apresentada à Université Sorbonne Nouvelle - Paris 3, inédita.

Ishaghpour, Youssef; Kiarostami, Abbas. 2004. Abbas Kiarostami. São Paulo: Cosac Naify/ Mostra Internacional de Cinema.

Ishaghpour, Youssef. 2010. "Kiarostami hors ses murs: Copie conforme". Traffic 75 (outono): 30-38.

Mulvey, Laura. 2006. Death $24 x$ a second: stillness and the moving image. Londres: Reaktion Books. 